\title{
Microstructural Evolution in Chroming Coatings Friction Pairs under Dry Sliding Test Conditions
}

\author{
Xin Wang, ${ }^{1,2,3}$ Rulin Zhang, ${ }^{1}$ Tao Zhou, ${ }^{1}$ Xicheng Wei ${ }^{D},{ }^{2}$ Peter Liaw, ${ }^{4}$ Rui Feng, \\ Wurong Wang, ${ }^{2}$ and Rongbin $\mathrm{Li} i^{1,3}$ \\ ${ }^{1}$ School of Materials Science and Engineering, Shanghai Dian Ji University, 1350 Ganlan Rd., Shanghai 201406, China \\ ${ }^{2}$ School of Materials Science and Engineering, Shanghai University, 149 Yanchang Rd., Shanghai 200072, China \\ ${ }^{3}$ Institute of Energy Equipment Materials, Shanghai Dian Ji University, 1350 Ganlan Rd., Shanghai 201406, China \\ ${ }^{4}$ Department of Materials Science and Engineering, University of Tennessee, Knoxville, TN 37909, USA
}

Correspondence should be addressed to Rongbin Li; lirb@sdju.edu.cn

Received 18 October 2017; Revised 5 January 2018; Accepted 11 January 2018; Published 7 February 2018

Academic Editor: Dae-Eun Kim

Copyright (C) 2018 Xin Wang et al. This is an open access article distributed under the Creative Commons Attribution License, which permits unrestricted use, distribution, and reproduction in any medium, provided the original work is properly cited.

\begin{abstract}
The microstructures of subsurface layers of $20 \mathrm{CrMnTi}$ steel pins against chroming and nonchroming T10 under dry sliding tests were studied by means of OM (optical microscopy), XRD (X-ray diffraction), and SEM (scanning electron microscopy). Results showed that the chroming coating strengthened the disc surface and significantly affected microstructural evolution. Three layers - the matrix, deformation layer (DL), and surface layer (SL) - formed in 20CrMnTi for the chroming T10. The matrix and deformation layer (DL) formed in $20 \mathrm{CrMnTi}$ for the nonchroming T10. The formation of the microstructure was considered as a result of the shear deformation.
\end{abstract}

\section{Introduction}

Chroming is an interesting and intriguing coating technology. How the chroming coatings protect the substrate material interests both materials academic and technological communities [1-5]. Literature rarely reports the systematic study on the application of chroming coatings on carbon steel, the most important material for mechanical components and their tribological performance evaluation [6]. A reasonable database is provided for the further application of chromeplating coating in tool steel engineering; it is worthwhile to investigate the friction and wear behaviors of chroming coatings and the substrate materials [7].

The microstructure evolution of ferrous alloy surface layer studied in [8] is beneficial to optimize the properties of surface chroming coatings on steels. Meanwhile, studying the chromium compounds layer of steel can help us extend the life of mechanical components.

Our group has concentrated on improving surface properties of the T10 tool steel using the surface chroming coatings, which can satisfy the requirements of machining operation.
The focus in this manuscript is to systematically investigate the microstructural evolution in advanced structural carbon steel friction pairs with and without chroming coatings under dry sliding testing conditions.

\section{Methods}

2.1. Materials and Tribological Experiment. The 20CrMnTi steel contains $0.2 \% \mathrm{C}, 1.2 \% \mathrm{Cr}, 0.1 \% \mathrm{Ti}, 0.95 \% \mathrm{Mn}$, and Fe balance, and the T10 steel contains $0.98 \% \mathrm{C}$ and Fe balance. The original 20CrMnTi steel pins have hardness of about $200 \mathrm{HB}$ ( $R a, 0.05 \mu \mathrm{m}$ to $0.1 \mu \mathrm{m}$ ). The chroming and nonchroming T10 steel discs have hardness of about $590 \mathrm{HB}$ and $180 \mathrm{HB}$ $(R a, 0.05 \mu \mathrm{m}$ to $0.33 \mu \mathrm{m})$, respectively. The conventional powder pack cementation method $[9,10]$ was applied to produce the chroming coating on T10 steel discs. The operation of the powder filling process is $1273 \mathrm{~K}$ and lasts 24 hours. This parameter is derived from the orthogonal test [11].

Friction and wear behaviors of chroming and nonchroming T10 steel discs were evaluated by laboratory tests, which were performed on the MM-W1 friction testing machine. All 


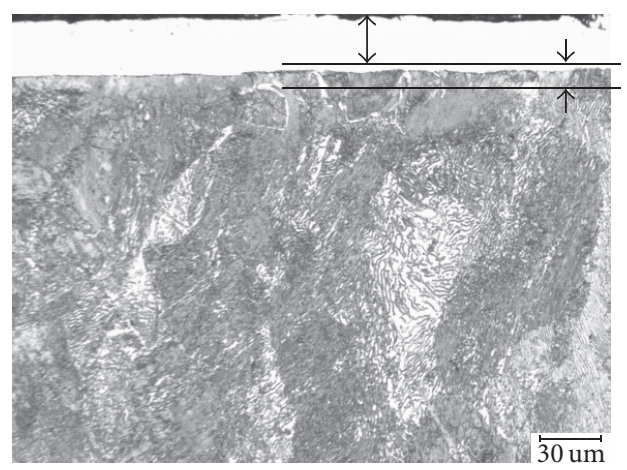

(a)

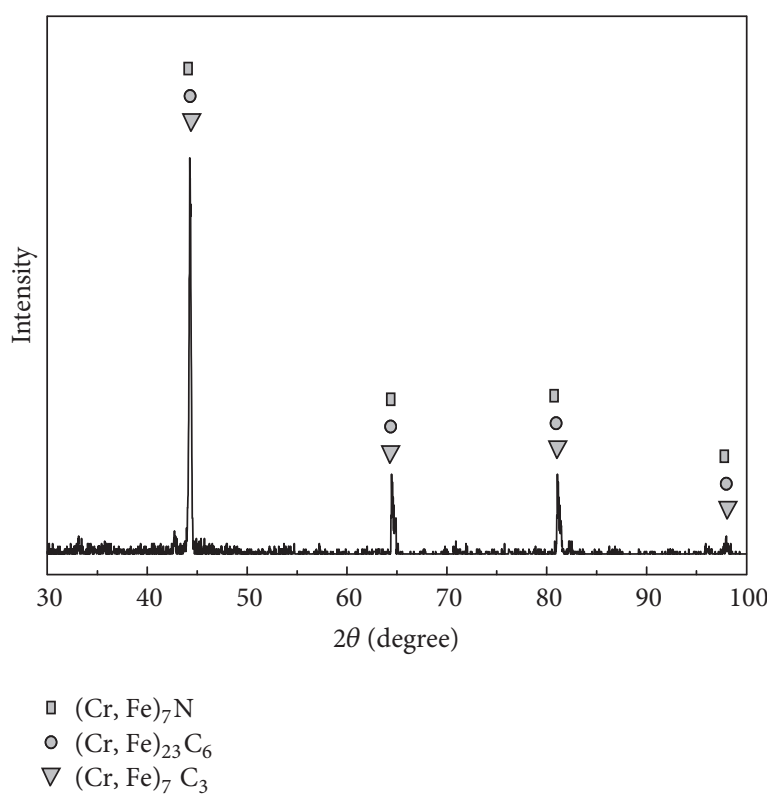

(b)

FIGURE 1: (a) OM micrograph of chroming layer; (b) XRD spectra of chroming coatings.

experiments were taken with a speed of $0.3 \mathrm{~m} / \mathrm{s}$, with load of $60 \mathrm{~N}$, for 2 hours, and at $300 \mathrm{~K}$. Friction coefficients were recorded online in a computer during the test.

2.2. Analysis and Characterization Methods. The chroming coating of T10 was observed with a Nikon optical microscope. The constituents were detected with a MAX2550V X-ray diffractometer (XRD).

Wear scars and the cross-section microstructures of chroming and nonchroming T10 discs and the worn surface layers of 20CrMiTi pins after the dry sliding test were observed by a HITACHI S-570 scanning electron microscope.

A microhardness tester (MH-3) was used to measure the microhardness distribution across the cross-section of 20CrMnTi pins against the chroming and nonchroming T10 steel discs using a Vickers indenter under a load of HV0.01 with a dwell time of $20 \mathrm{~s}$.

\section{Results}

3.1. Microstructural Characterizations of Chroming T10 Steel Disc. The coating sectional area OM image is shown in Figure 1(a). The results show that the chrome-plating layer is homogeneous and there is no obvious boundary between the interfaces. The average coating thickness is about $35 \mu \mathrm{m}$.

Figure 1(a) shows that the coating is made up of two different colors and is represented by two arrows. The outer layer belongs to the composite layer (rich in chromium), which corresponds to the chrome-diffusion zone [12].

Figure $1(\mathrm{~b})$ shows the XRD results of chromized coating. The results showed that chrome-plated coating was mainly

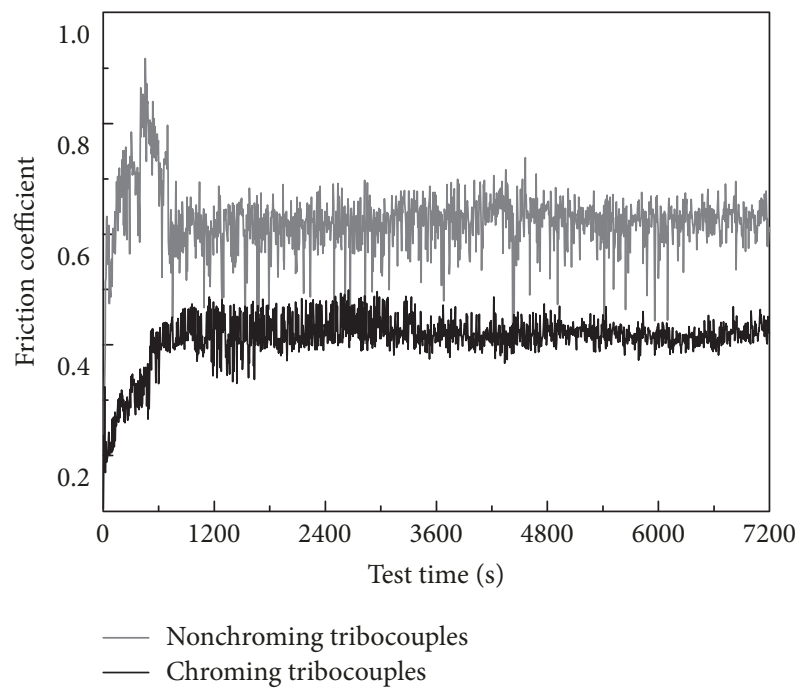

FIGURE 2: Friction coefficient versus friction time for the nonchroming and chroming friction pairs.

composed of $(\mathrm{Cr}, \mathrm{Fe})_{23} \mathrm{C}_{6},(\mathrm{Cr}, \mathrm{Fe})_{7} \mathrm{C}_{3}$, and several diffraction peaks of $(\mathrm{Cr}, \mathrm{Fe})_{7} \mathrm{~N}[13]$.

3.2. Tribological Performance. The friction coefficients versus friction time for chroming and nonchroming coated T10 steel discs against 20CrMnTi steel pins were illustrated in Figure 2. An average friction coefficient around 0.4 has been observed for the chroming coating, indicating good wear resistance [14]. However, the average friction coefficient of 


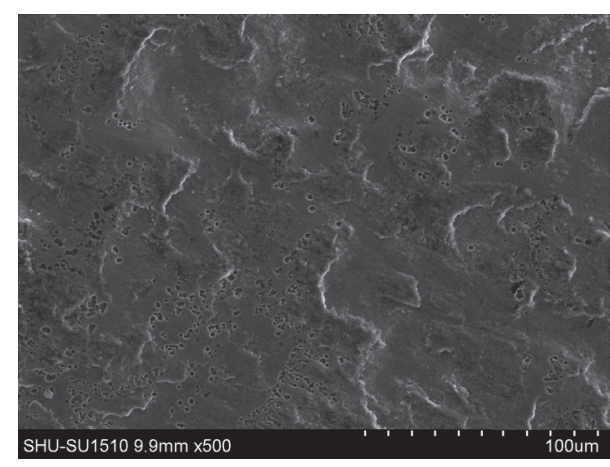

(a)

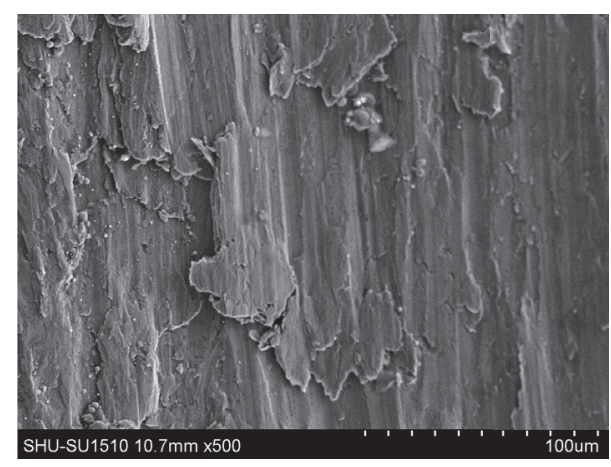

(b)

FIgURE 3: Wear scars of (a) chroming and (b) nonchroming T10 discs after dry sliding.

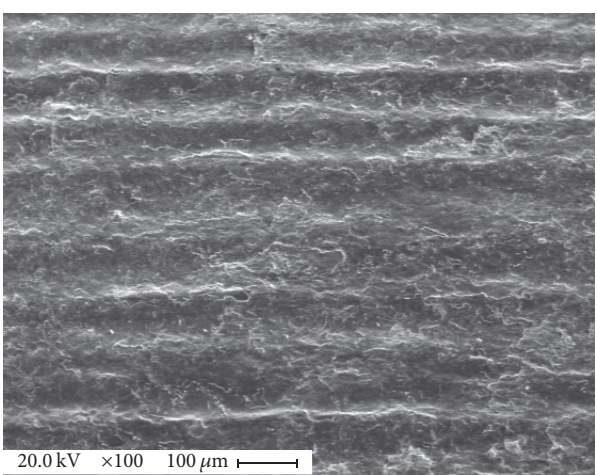

(a)

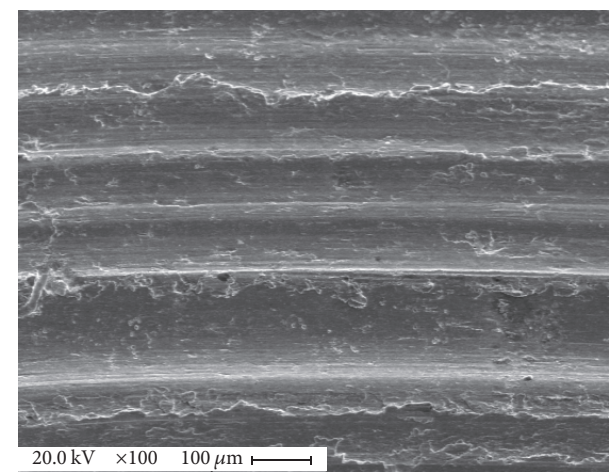

(b)

FIGURE 4: Wear scars of (a) 20CrMnTi pins against chroming T10 disc and (b) 20CrMnTi pins against nonchroming T10 disc after dry sliding.

the nonchroming coating has reached 0.9 at 400 seconds and then dropped to around 0.6 in the first 600 seconds of the friction time. Table 1 shows wear loss and wear rate of chroming/nonchroming T10 discs against 20CrMnTi pin.

Wear-scar morphologies of the chroming and nonchroming T10 steel discs against 20CrMnTi pins after dry friction test are shown in Figure 3. The visible slight characteristics of plastic deformation are found, which may be attributed to the chromium coating of T10 steel in Figure 3(a). The chroming layer is involved in friction and is crushed into small grinding particles, resulting in abrasion wear [15]. The local plastic deformation zone of the nonchromium T10 steel and abrasion wear caused by 20CrMnTi is revealed in Figure 3(b). Wear scars of 20CrMnTi pins against chroming T10 disc and 20CrMnTi pins against nonchroming T10 disc after dry friction test are shown in Figure 4.

The SEM cross-section micrographs of the chroming and nonchroming T10 discs against 20CrMnTi steel pins after dry sliding are shown in Figure 5. It exhibits the microstructural changes from the worn surface into the matrix with the different wear mechanisms. Figure 5(a) indicates that there was a severely damaged chroming layer on the T10 steel disc. The matrix was not destroyed under the protection of the chroming layer [14]. The plastic flow lines of nonchroming T10 steel disc in the SFIDL are exhibited in Figure 5(b). The deformation direction of microstructure is consistent with sliding direction [14]. The matrix has deformed due to the friction which may be caused by plastic wave, ploughing, shearing, and cutting [16]. As a result, the detachment of particles that form wear debris occurs and the scratched surface (Figure 3(b)) with cracked subsurface (Figure 5(b)) has been observed.

3.3. Microstructure of 20CrMnTi against Chroming and Nonchroming T10 Steel. Figure 6 shows the microstructure of 20CrMnTi against chroming and nonchroming T10 steel by SEM.

Figure 6(a) reveals three distinct layers versus the distance from the surface.

(i) $>150 \mu \mathrm{m}$ from the Surface. The matrix was hardly affected by the friction shear force.

(ii) 150 20 $\mu \mathrm{m}$ from the Surface. The deformation layer (DL) consisted of structures induced by considerable plastic and shear deformation.

(iii) 20 0 $\mu \mathrm{m}$ from the Surface. The surface layer (SL) had been mechanically damaged.

Note that Figure 6(b) shows only two layers of the 20CrMnTi pin against the nonchroming T10 steel disc.

(i) $>150 \mu \mathrm{m}$ from the Surface. The matrix was hardly affected by the friction shear force. 
TABLE 1: Wear loss and wear rate of chroming/nonchroming T10 discs against 20CrMnTi pin.

\begin{tabular}{lcr}
\hline & Mass losses $(\mathrm{g})$ & Wear rate $(\mathrm{g} / \mathrm{m})$ \\
\hline Chroming T10 disc/20CrMnTi pin & $10.63 \times 10^{-3} / 46.28 \times 10^{-3}$ & $4.92 \times 10^{-6} / 21.43 \times 10^{-6}$ \\
Nonchroming T10 disc/20CrMnTi pin & $16.72 \times 10^{-3} / 23.68 \times 10^{-3}$ & $7.74 \times 10^{-6} / 10.96 \times 10^{-6}$ \\
\hline
\end{tabular}

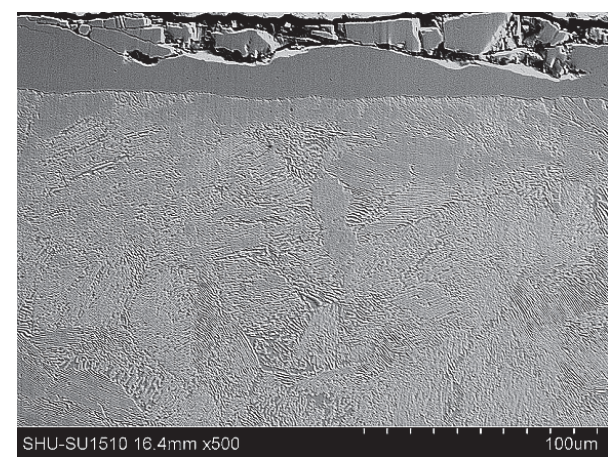

(a)

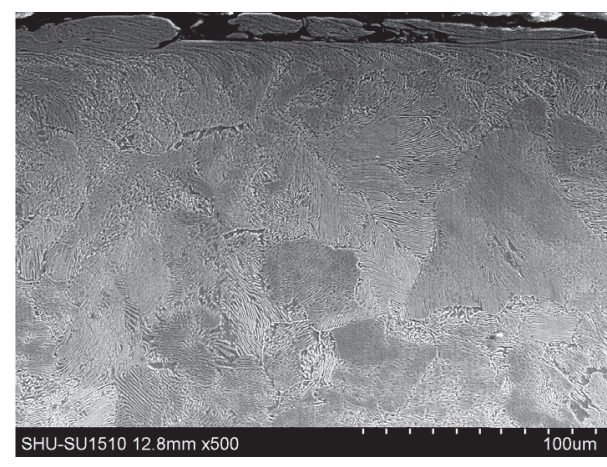

(b)

FIGURE 5: SEM cross-section micrographs of the (a) chroming and (b) nonchroming T10 discs.

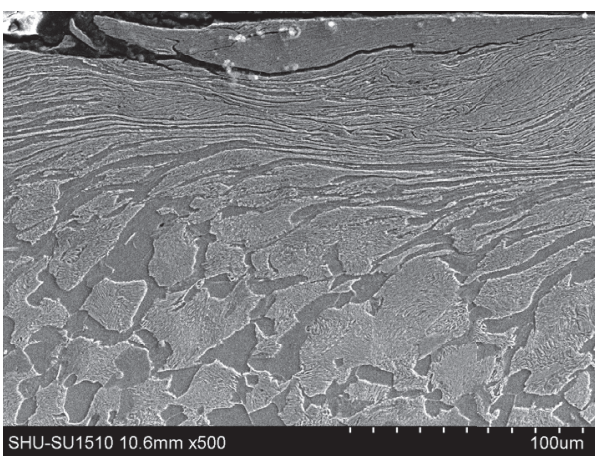

(a)

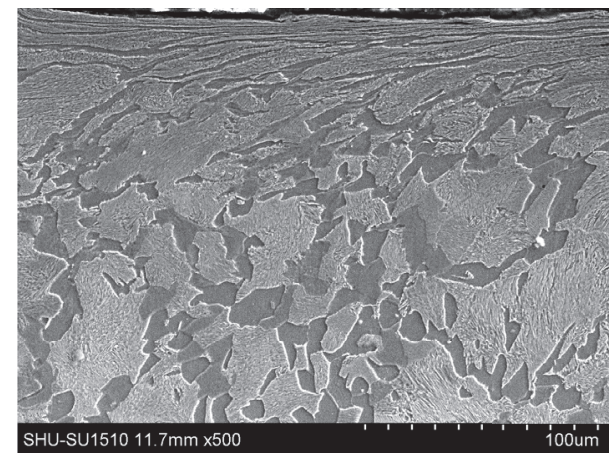

(b)

FIGURE 6: SEM images of the worn subsurface layers of 20CrMnTi pins against the (a) chroming and (b) nonchroming T10 discs.

(ii) 100 20 $\mathrm{\mu m}$ from the Surface. The deformation layer (DL) makes the ferrite+pearlite microstructure gradually incline to be parallel to the surface, which is similar to those structures deformed by particle bombardment such as rolling [17] and shot peening [18].

Thus, the chroming layer made its counterpart go through more severe and deeper plastic deformation than the nonchroming one. In other words, the chroming layer might protect its matrix materials much better than the nonchroming one.

3.4. Microhardness of 20CrMnTi against Chroming and Nonchroming T10. For the 20CrMnTi against the chroming T10 in Figure 7, (i) for $0-20 \mu \mathrm{m}$, the microhardness gradually increased to $1100 \mathrm{HV}$; (ii) for $20-25 \mu \mathrm{m}$, the microhardness decreased sharply to $300 \mathrm{HV}$; (iii) and finally, after the depth reached $25 \mu \mathrm{m}$, the microhardness went around $300 \mathrm{HV}$ without variation.

For the 20CrMnTi against the nonchroming T10 in Figure 7, (i) for $0-10 \mu \mathrm{m}$, the microhardness gradually increased to $1200 \mathrm{HV}$; (ii) for $10-25 \mu \mathrm{m}$, the microhardness decreased sharply to $300 \mathrm{HV}$; (iii) and finally, after the depth reached $25 \mu \mathrm{m}$, the microhardness became around $300 \mathrm{HV}$ without variation.

\section{Discussion}

4.1. Wear Mechanism of Chroming and Nonchroming Friction Pairs. According to the above experimental results, the chroming and nonchroming T10 discs have different hardness and microstructures. Thus, they present different wear mechanisms for the 20CrMnTi steel pins. The wear mechanism of the chroming T10 steel disc is mild oxidation wear [19-21]. This might be judged from the shallow wear surface scratches. The chroming T10 steel disc is able to withstand severe plastic deformation for a long worn period [22, 23].

In contrast, the wear mechanism of the nonchroming T10 steel disc is delamination wear, owing to plastic deformation $[22,23]$. The dominance of delamination wear is due to the slightly higher hardness of the original 20CrMnTi steel pin relative to nonchroming T10 steel disc. Unlike the chroming 


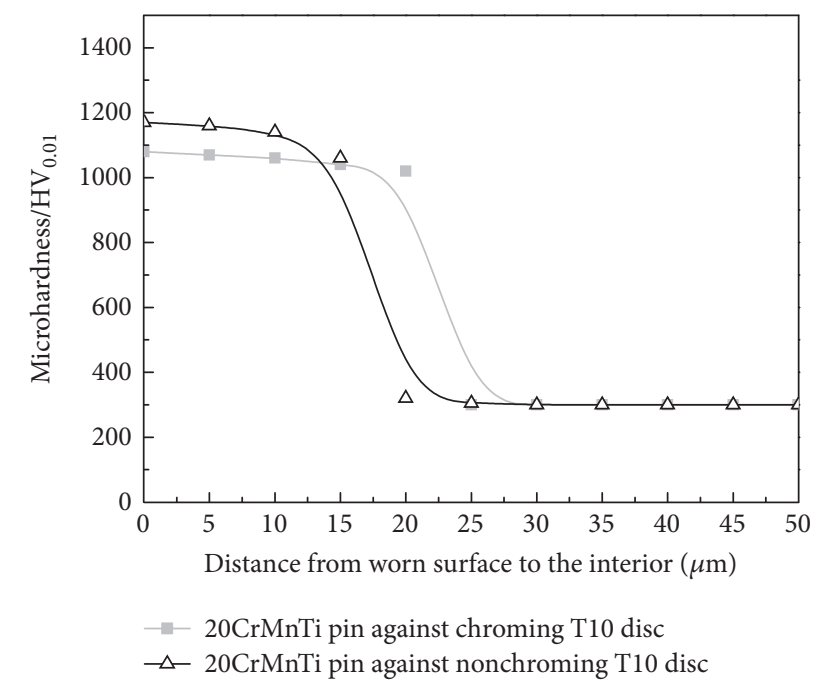

Figure 7: Microhardness profiles of 20CrMnTi pins against (a) chroming and (b) nonchroming T10 discs as a function of the depth beneath worn surface.

friction pair, the nonchroming T10 disc could only be divided into two distinct layers beneath after the worn test (Figure 5(b)). There was no mechanical mixing layer (MML) beneath the worn surface. It is speculated that the MML has also been formed, but it was quickly worn out, owing to the higher shear stresses.

\subsection{Mechanism of Wear Resistance in Chroming T10 Steel Disc.} The 20CrMiTi pin against nonchroming T10 disc would be more softened and worn than the pin against the chroming friction pair [24]. Hence, the microstructures (Figure 5) also confirmed the opinion stated above that only two layers existed in 20CrMnTi pin against the nonchroming T10 disc, compared with the three layers in the 20CrMnTi pin against the chroming T10 disc.

Furthermore, the chroming T10 protected its matrix materials from being seriously damaged, and only some microcracks occurred in the chroming layer without endangering the substrate material (Figure 5(a)). Unfortunately, the nonchroming T10 disc and its counterpart 20CrMnTi pin were both affected seriously by the shear deformation during the sliding (Figures 5(b) and 6(b)), owing to the mechanical mixing layer (MML) having been worn out.

The mechanism of the outstanding wear resistance in the chroming T10 steel discs is considered to be the formation in the 20CrMnTi pin, which helped them undergo less severe shear deformation than the nonchroming friction pair.

\section{Conclusions}

The microstructures of subsurface layers of $20 \mathrm{CrMnTi}$ against chroming and nonchroming T10 under dry sliding tests were observed. Some conclusions were drawn:

(1) The friction coefficient of chroming friction coefficient is considered, and the antifriction properties of chrome-plating layer have a strong influence on the surface chroming layer.

(2) Three layers, which corresponded to matrix, DL, and SL, were observed beneath the worn surface in the 20CrMnTi against the chroming T10. Matrix and DL were observed in the $20 \mathrm{CrMnTi}$ against the nonchroming T10.

(3) The mechanism of the outstanding wear resistance in the chroming friction pair is considered to be the formation of the SFIDL in the 20CrMnTi. The SFIDL help them undergo less severe shear deformation than the nonchroming friction pair.

\section{Conflicts of Interest}

The authors declare that there are no conflicts of interest regarding the publication of this paper.

\section{Acknowledgments}

The present work was supported by the National Natural Science Foundation of China (Grant no. 11372226), the Outstanding Young Teachers' Special Funding of Shanghai Municipal Education Commission (ZZSDJ14007), the Scientific Research Innovation Project of Shanghai Municipal Education Commission (15ZZ104), and the Science and Technology Sail Plan of Shanghai Science and Technology Commission (15YF1404400).

\section{References}

[1] Z. B. Wang, J. Lu, and K. Lu, "Wear and corrosion properties of a low carbon steel processed by means of SMAT followed by lower temperature chromizing treatment," Surface and Coatings Technology, vol. 201, no. 6, pp. 2796-2801, 2006.

[2] N.-M. Lin, F.-Q. Xie, J. Zhou, T. Zhong, X.-Q. Wu, and W. Tian, "Microstructures and wear resistance of chromium coatings on P110 steel fabricated by pack cementation," Journal of Central South University of Technology (English Edition), vol. 17, no. 6, pp. 1155-1162, 2010.

[3] G. Bikulčius, A. Češunienè, A. Selskienè, V. Pakštas, and T. Matijošius, "Dry sliding tribological behavior of $\mathrm{Cr}$ coatings electrodeposited in trivalent chromium sulphate baths," Surface and Coatings Technology, vol. 315, pp. 130-138, 2017.

[4] F. Hakami, M. H. Sohi, J. R. Ghani, and M. Ebrahimi, "Chromizing of plasma nitrided AISI 1045 steel," Thin Solid Films, vol. 519, no. 20, pp. 6783-6786, 2011.

[5] J. D. B. De Mello, J. L. Gonçalves, and H. L. Costa, "Influence of surface texturing and hard chromium coating on the wear of steels used in cold rolling mill rolls," Wear, vol. 302, no. 1-2, pp. 1295-1309, 2013.

[6] L. Shan, Y. Wang, J. Li, X. Jiang, and J. Chen, "Improving tribological performance of $\mathrm{CrN}$ coatings in seawater by structure design," Tribology International, vol. 82, pp. 78-88, 2015.

[7] K. Widi A, I. Wardana, W. Suprapto et al., "The Role of Diffusion Media in Nitriding Process onSurface Layers Characteristics of AISI 4140 with and without Hard Chrome Coatings," Tribology in Industry, vol. 38, no. 3, 2016. 
[8] Z. B. Wang, J. Lu, and K. Lu, "Chromizing behaviors of a low carbon steel processed by means of surface mechanical attrition treatment," Acta Materialia, vol. 53, no. 7, pp. 2081-2089, 2005.

[9] S. A. Tsipas, H. Omar, F. H. Perez, and D. N. Tsipas, "Boroaluminide coatings on ferritic-martensitic steel deposited by lowtemperature pack cementation," Surface and Coatings Technology, vol. 202, no. 14, pp. 3263-3271, 2008.

[10] X. M. Peng, C. Q. Xia, Y. Y. Liu, and J. H. Wang, "Surface molybdenizing on titanium by halide-activated pack cementation," Surface and Coatings Technology, vol. 203, no. 20-21, pp. 33063311, 2009.

[11] N. Lin, F. Xie, T. Zhong, X. Wu, and W. Tian, "Influence of adding various rare earths on microstructures and corrosion resistance of chromizing coatings prepared via pack cementation on P110 steel," Journal of Rare Earths, vol. 28, no. 2, pp. 301-304, 2010.

[12] N. Lin, F. Xie, X. Wu, and W. Tian, "Influence of process parameters on thickness and wear resistance of rare earth modified chromium coatings on P110 steel synthesized by pack cementation," Journal of Rare Earths, vol. 29, no. 4, pp. 396-400, 2011.

[13] F.-S. Chen, P.-Y. Lee, and M.-C. Yeh, “Thermal reactive deposition coating of chromium carbide on die steel in a fluidized bed furnace," Materials Chemistry and Physics, vol. 53, no. 1, pp. 19-27, 1998.

[14] J.-W. Lee, J.-G. Duh, and S.-Y. Tsai, “Corrosion resistance and microstructural evaluation of the chromized coating process in a dual phase Fe-Mn-Al-Cr alloy," Surface and Coatings Technology, vol. 153, no. 1, pp. 59-66, 2002.

[15] C.-Y. Wei and F.-S. Chen, "Characterization on multi-layer fabricated by TRD and plasma nitriding," Materials Chemistry and Physics, vol. 90, no. 1, pp. 178-184, 2005.

[16] N. Bay and T. Wanheim, "Contact phenomena under bulk plastic deformation conditions, Symposium on lubrication mechanisms in metal forming at 3rd international conference on technology of plasticity," in Proceedings of the Third International Conference on Technology of Plasticity, vol. I, pp. 16771691, Kyoto, Japan, 1990.

[17] M. Sato, P. M. Anderson, and D. A. Rigney, "Rolling-sliding behavior of rail steels," Wear, vol. 162-164, pp. 159-172, 1993.

[18] X. Zhang, N. Hansen, Y. Gao, and X. Huang, "Hall-Petch and dislocation strengthening in graded nanostructured steel," Acta Materialia, vol. 60, no. 16, pp. 5933-5943, 2012.

[19] M. F. Ashby and S. C. Lim, "Wear-mechanism maps," Scripta Metallurgica Et Materiala, vol. 24, no. 5, pp. 805-810, 1990.

[20] T. F. J. Quinn, "Review of oxidational wear. Part I: The origins of oxidational wear," Tribology International, vol. 16, no. 5, pp. 257-271, 1983.

[21] F. H. Stott, “The role of oxidation in the wear of alloys," Tribology International, vol. 31, no. 1-3, pp. 61-71, 1998.

[22] N. P. Suh, “The delamination theory of wear," Wear, vol. 25, no. 1, pp. 111-124, 1973.

[23] N. P. Suh, "An overview of the delamination theory of wear," Wear, vol. 44, no. 1, pp. 1-16, 1977.

[24] G. Straffelini, M. Pellizzari, and A. Molinari, "Influence of load and temperature on the dry sliding behaviour of Al-based metal-matrix-composites against friction material," Wear, vol. 256, no. 7-8, pp. 754-763, 2004. 


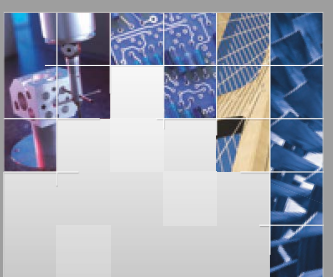

\section{Enfincering}
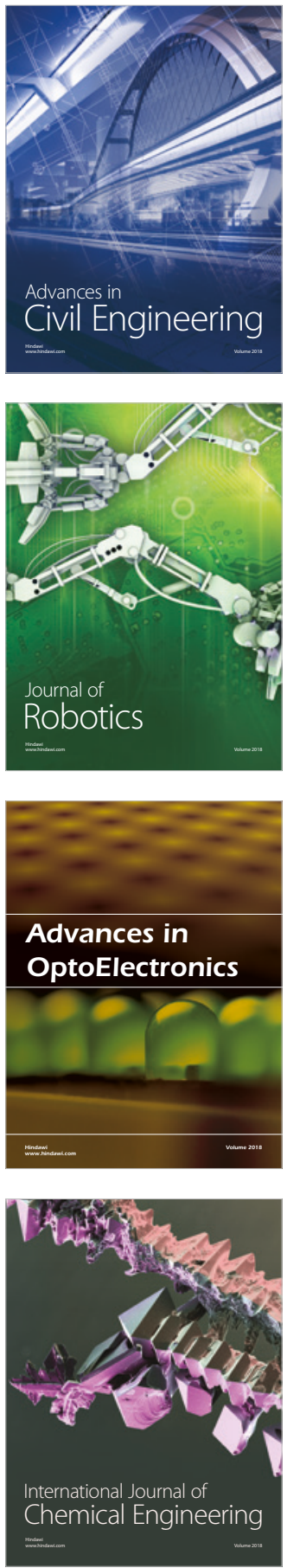

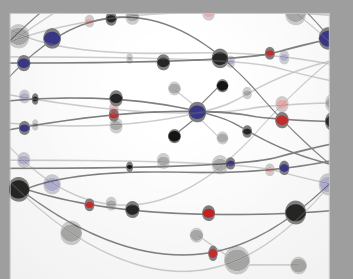

\section{Rotating \\ Machinery}

The Scientific World Journal

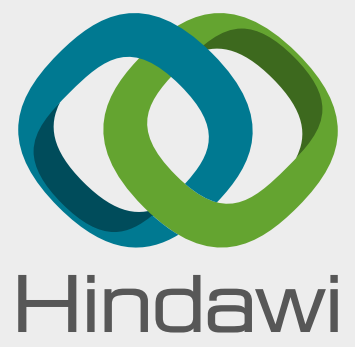

Submit your manuscripts at

www.hindawi.com
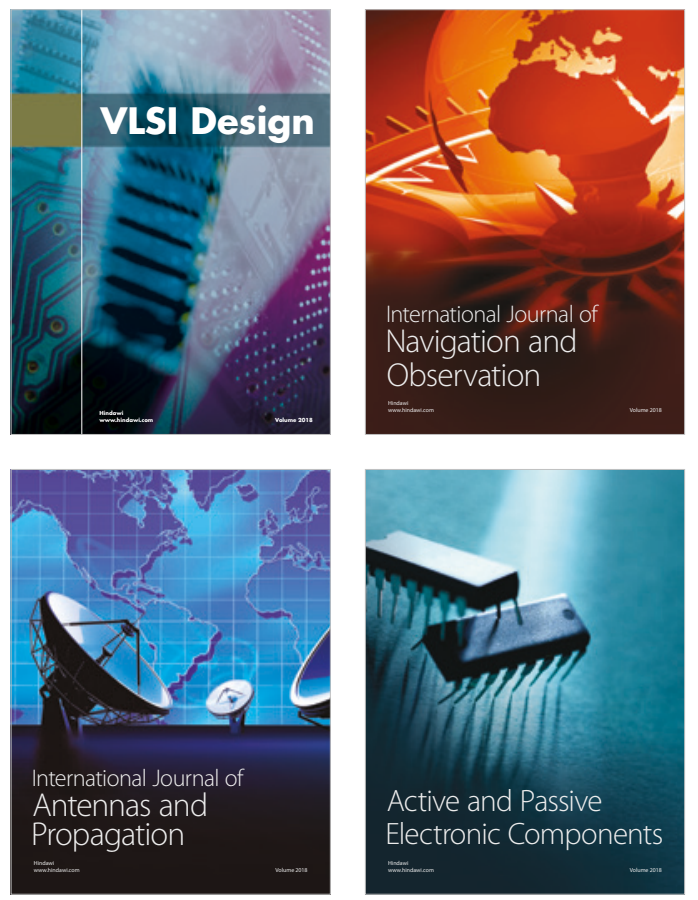
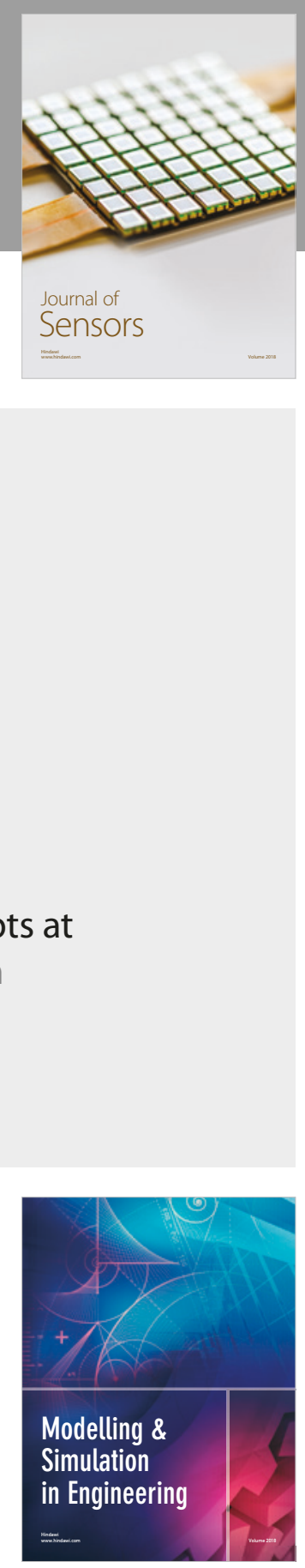

\section{Advances \\ Multimedia}
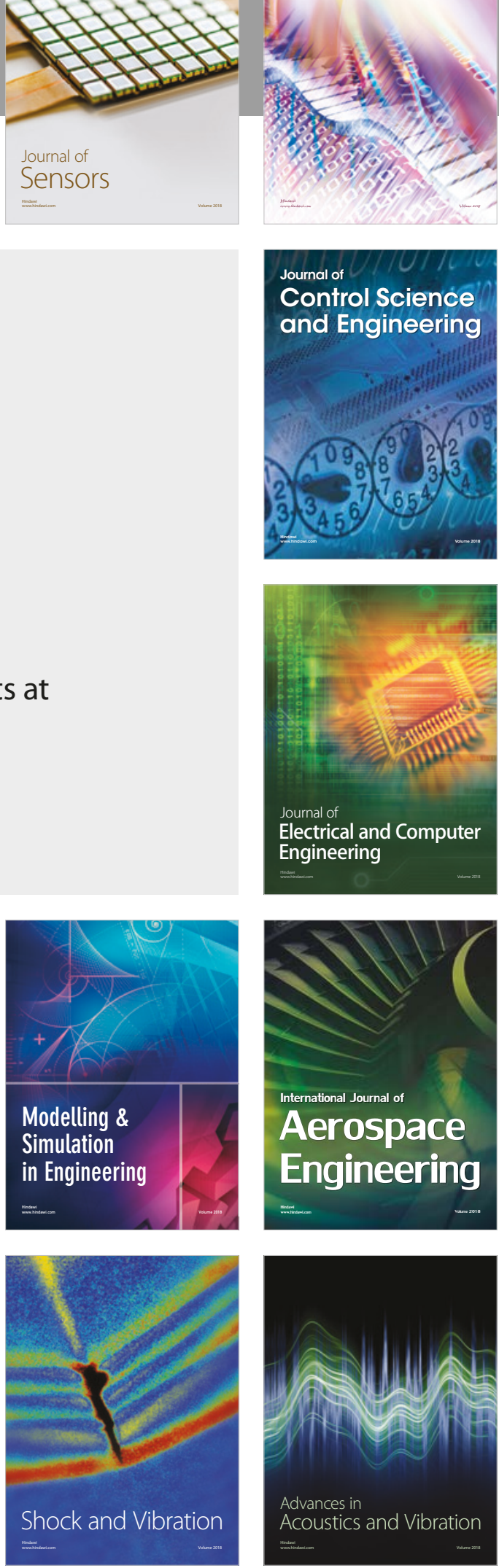